\title{
TANTANGAN PEWIRAUSAHA DI BIDANG TI: BAGAIMANA MENGHASILKAN KEUNTUNGAN DARI IDE? STUDI KASUS PADA PT “IPS” (PAYMENT GATEWAY)
}

\author{
Yuliana Lisanti \\ Information Systems Department, School of Information Systems, Binus University \\ Jl. K.H. Syahdan No. 9, Palmerah, Jakarta Barat 11480 \\ lisanti@binus.edu
}

\begin{abstract}
It was not easy to start a business, let alone to run it. However, the spirit and ideas of the three founder of PT "IPS" has successfully created an innovative business that is a payment gateway to help sellers and buyers to make purchases online. However, there is a major problem for many IT entrepreneurs faced by PT "IPS" that is how to gain profit from the business. PT "IPS" hopes to make a profit from the efforts undertaken By understanding customer behavior and how other business people can get profit from the business relating to technology, such as improving customer value, distinguishing between types of member and amenities, providing "ignored" biaya by the user and working with other business people in the same field.
\end{abstract}

Keywords: entrepreneur, IT entrepreneur, customer behavior

\begin{abstract}
ABSTRAK
Tidak mudah untuk memulai suatu usaha, apalagi menjalankannya. Walaupun demikian, semangat dan ide dari ketiga founder PT "IPS" telah berhasil mewujudkan suatu bisnis yang tergolong inovatif, yaitu menjadi payment gateway untuk membantu para penjual dan pembeli melakukan pembelian secara online. Namun, ada suatu masalah utama bagi kebanyakan IT entrepreneur yang perlu dihadapi oleh PT "IPS", yaitu bagaimana mendapatkan keuntungan dari bisnisnya tersebut? Dengan memahami customer behaviour dan bagaimana pelaku bisnis lain bisa mendapatkan profit dari bisnis yang berhubungan dengan teknologi, seperti meningkatkan customer value, membedakan jenis member dan fasilitasnya, memberikan biaya yang "diabaikan" oleh penggunanya dan bekerja sama dengan pelaku bisnis lain di bidang yang sama, PT "IPS" diharapkan akan dapat membuat keuntungan dari usaha yang dijalankannya.
\end{abstract}

Kata kunci: enterpreneur, IT enterpreneur, customer behaviour 


\section{PENDAHULUAN}

“I have not failed. I've just found 10,000 ways that won't work." adalah kutipan populer dari Thomas Edison yang menunjukan betapa tidak mudahnya untuk membuat atau membangun sesuatu. Demikian juga dengan para pelaku entrepreneur atau wiraswasta yang kebanyakan memulai bisnisnya dari kecil. Berbagai kendala seperti modal yang terbatas, produk dan jasa yang bisa belum dikenal oleh market, sampai kepada masalah perijinan usaha merupakan tantangan yang harus dihadapi oleh para wirausahawan ini. Selain kemampuan, dukungan dan motivasi yang tinggi juga sangat diperlukan dalam melakukan kegiatan berwiraswasta.

Tidak hanya tantangan, kesempatan untuk maju sangat terbuka luas bagi para entrepreneur, terutama di bidang yang pada saat ini terus meningkat permintaanya, seperti bidang teknologi informasi, atau jenis bisnis lainnya yang melibatkan internet sebagai proses bisnis utamanya (ebusiness). Besarnya capital tidak selalu menjadi penentu dalam membangun usaha di bidang TI karena kegiatan usaha ini merupakan knowledge intensive sector. Inovasi adalah kunci utamanya, seperti bagaimana kita dapat menciptakan suatu produk yang disukai oleh market, atau layanan yang tepat didalam membantu usaha bisnis perusahaan lain, atau mendesain suatu proses bisnis yang baru yang dapat mempermudah kehidupan kita sehari-hari.

Namun demikan, memiliki suatu produk atau layanan yang inovatif bukan jaminan mencapai kesuksesan. Gans dan Stern (2002) di dalam jurnalnya "The product market and the market for "ideas": commercialization strategies for technology entrepreneurs" menyebutkan bahwa tantangan utama bagi technology entrepreneur adalah bagaimana membuat keuntungan dari sebuah produk atau layanan yang inovatif, sehingga masalah utama yang harus dihadapi itu adalah bagaimana membuat orang mau membayar terhadap produk atau layanan inovatif yang kita tawarkan, “... a key management challenge is how to translate promising technologies into a stream of economic returns for their founders, investors and employees. In other words, the main problem is not so much invention but commercialization" (Gans and Scott, 2002). Mengingat kondisi persaingan usaha di dunia TI yang sudah membentuk persepsi para pengguna bahwa produk atau layanan di internet itu bernilai nol atau gratis, Gans dan Scott sudah mengutarakan tantangan terberat bagi technology entrepreneur pada saat ini.

Lalu bagaimana cara IT entrepreneur di Indonesia membawa inovasi produk atau jasanya ke market? Apa yang sudah mereka lakukan untuk mendapatkan profit dari usahanya tersebut ? dan apa yang perlu mereka lakukan agar mendapatkan keuntungan dari inovasi-nya itu? Tulisan ini, selanjutkan akan difokuskan kepada menjawab pertanyaan diatas, selain studi pustaka, penulis juga melakukan deep interview kepada IT entrepreneur di Indonesia d online payment gateway (layanan pembayaran online).

\section{METODE}

Metode penelitian yang dilakukan menggunakan pendekatan penelitian kualitatif, yang menekankan pada pemahaman berdasarkan kondisi realitas yang bersifat subyektif dan berdimensi banyak. Peneliti akan berinteraksi dengan fakta yang di teliti dengan menggunakan pendekatan deduktif, di mana studi literatur diperlukan untuk memahami permasalahan yang sedang diteliti sehingga dari kondisi umum dapat ditarik kesimpulan yang lebih spesifik. Selain itu, Teknik pengumpulan data akan menggunakan teknik wawancara, yang dilakukan kepada subjek penelitian, dan observasi, untuk memahami proses bisnis, lingkungan objek yang diteliti sehingga peneliti dapat memahami permasalahan yang dihadapi dan mengusulkan solusi untuk masalah tersebut. 


\section{Techonolgy Acceptance Model}

Jessup Umesh, Len dan Huynh, Minh Q (2007) dalam jurnalnya yang berjudul "Current issues faced by today technology entrepreneurs" menuliskan bahwa sering kali, bukan ide yang terhebat yang dapat mendominasi market, tetapi ide yang yang paling efisien dan efektif untuk menghilangkan semua langkah, hambatan, dan masalah, yang dapat diterima oleh market dan bisa menghasilkan keuntungan. Untuk dapat masuk dan diterima oleh market, technology entrepreneur perlu untuk berkonsultasi dan bekerja sama dengan customernya. Selain itu desain produk, secara fundamental harus di rancang dengan memperhatikan dari kompatibilitas dengan hardware, software, security dan infastruktur networking yang ada dan populer untuk dapat diterima oleh market.

Technology Acceptance model (TAM) yang di perkenalkan oleh Davis, Fred (1985) merupakan salah satu model populer yang dapat digunakan oleh entrepreneur untuk mendesain produknya sehingga dapat diterima oleh market. Davis, Fred (1985) menyebutkan bahwa motivasi pengguna (user) dapat dijelaskan oleh tiga faktor utama, yaitu perceived usefulness (manfaat yang dirasakan), perceived ease of use (kemudahan penggunaan yang dirasakan) dan attitude toward using (sikap terhadap penggunaan). Ketiga faktor tersebut dipengaruhi oleh karakteristik dari teknologi yangi diwakili dengan x1, x2 dan x3 (Gambar 1)

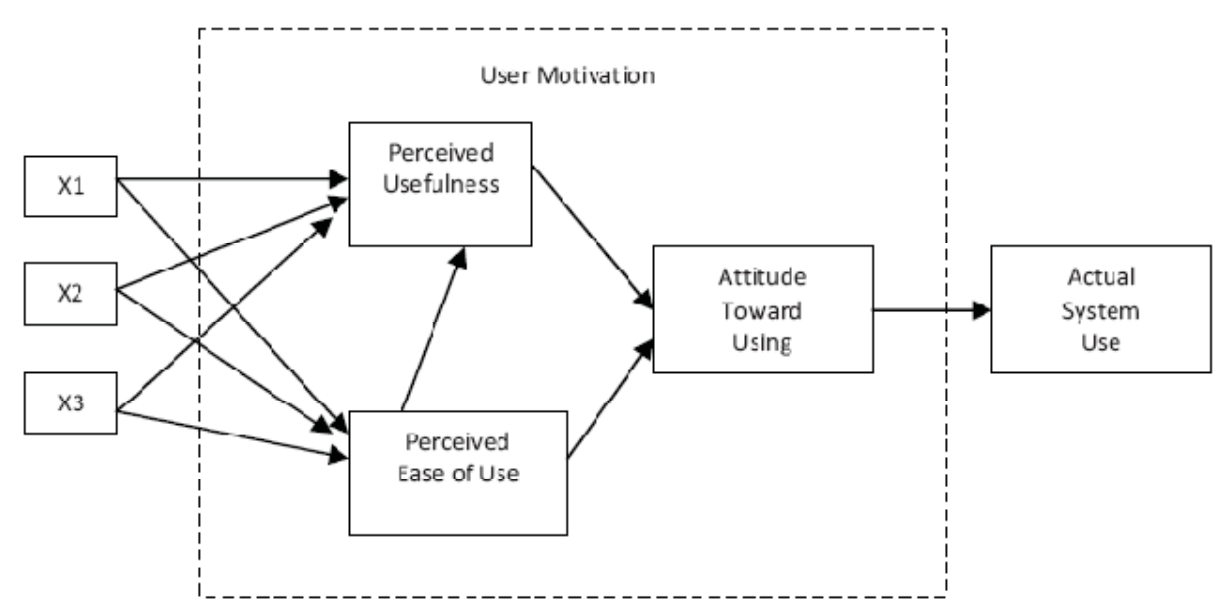

Gambar 1 Model Original TAM (Davis, 1985)

\section{Techonolgy Acceptance and Market Succesful Model}

Fred Davis, Jessup Umesh, Len dan Huynh, Minh Q (2007), mengusulkan konsep Technology Acceptance and Market Succesfull model (TAMSM) seperti yang di ilustrasikan pada Gambar 2 (Technology Acceptance and Market Succesfull model), bahwa capital (yang berupa finansial) yang akan mempengaruhi kemampuan sebuah perusahaan mendapatkan pegawai yang mampu, juga outsourcing, akan menghasilkan produk yang bermanfaat dan mudah di gunakan (easy to use and useful), sehingga akan mendorong orang untuk menggunakan produk tersebut sehingga produk dapat diterima oleh market. Selain itu juga mengatakan bahwa tingkat pendidikan dan kemampuan (seperti IT literate) customer yang ada didalam market akan mendorong penggunaan produk dan secara bersama-sama dapat mendorong kesuksesan produk untuk dapat diterima oleh market. 


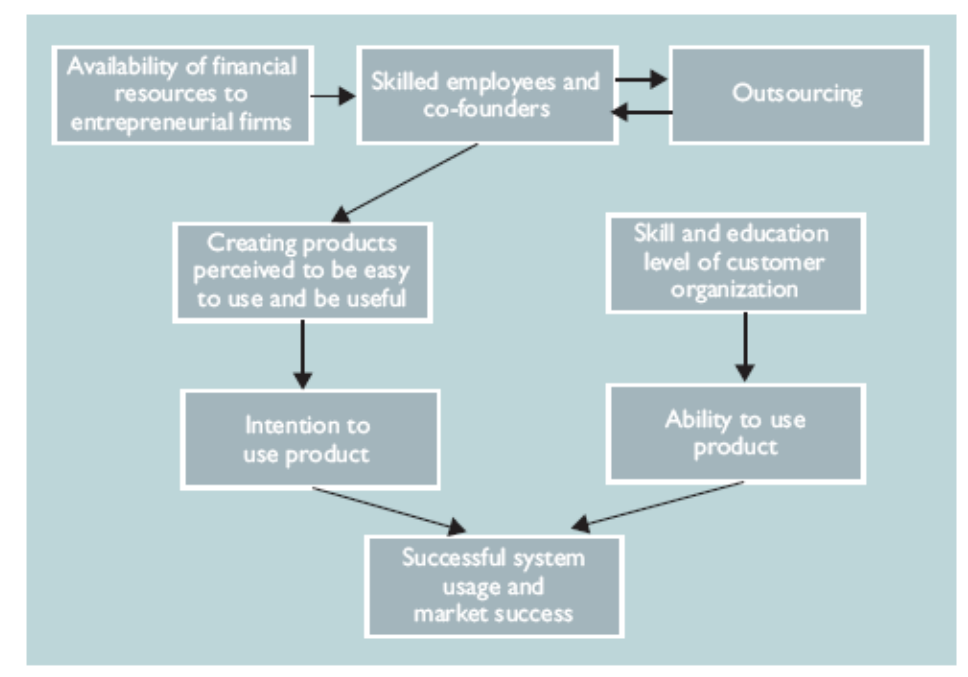

Gambar 2 Technology Acceptance and Market Succesfull model

\section{HASIL DAN PEMBAHASAN}

\section{PT "IPS" - Online Payment Gateway}

Tiga sekawan dari satu alumni perguruan tinggi IT di Jakarta memulai usaha ini pada akhir tahun 2011. Berawal dari pengalaman berbelanja online melalui media internet, mereka melihat peluang bisnis untuk memberikan layanan jasa menjadi fasilitator atau mediator didalam melindungi kepentingan Pembeli dan Penjual yang melakukan bisnisnya melalui media internet. Ide ini kemudian di wujudkan dalam bentuk suatu proses bisnis yang sudah dapat diterima oleh market, khususnya para penjual dan pembeli melalui media internet.

Berikut adalah proses bisnis PT "IPS”: (1) pembeli dan penjual setuju melakukan transaksi menggunakan layanan PT "IPS”; (2) pembeli melakukan pembayaran/transfer ke PT "IPS” sesuai dengan nilai barang yang sudah disepakati antara pembeli dan penjual; (3) PT "IPS" akan menampung sementara pembayaran tersebut dan menginformasikan kepada penjual bahwa pembeli sudah melakukan pembayaran dan penjual dapat melakukan pengiriman barang yang dipesan oleh pembeli tadi; (4) setelah pembeli menerima barang tersebut, maka pembeli akan menginformasikan ke pihak PT "IPS” bahwa barang yang dipesan sudah diterima dengan baik dan sesuai lalu pembayaran ke penjual dapat dilakukan; (5) penjual akan menerima pembayaran dari PT "IPS". Gambar 3 menunjukan bagaimana layanan yang diberikan oleh PT "IPS”.

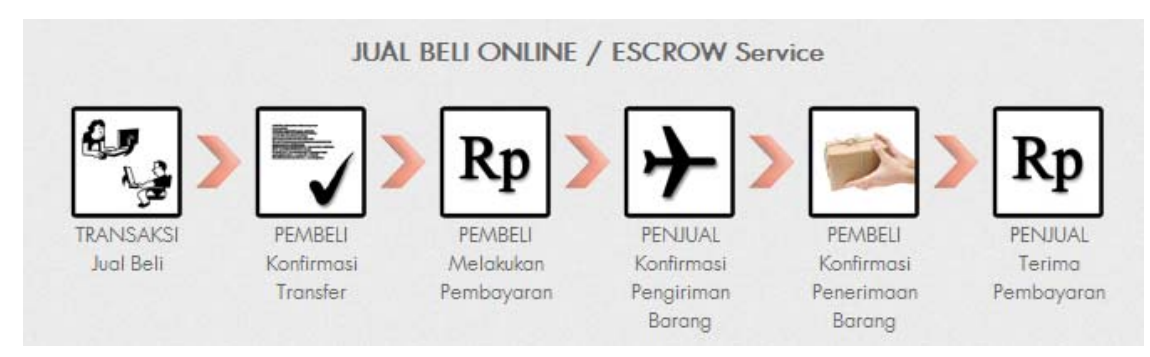

Gambar 3 Proses Bisnis layanan mediasi PT “IPS” (sumber : website PT “IPS”) 
Selain memberikan rasa keamanan dalam berbelanja, PT “IPS” juga memberikan benefit lain seperti adanya jaminan Money Back Guarantee jika terjadi penipuan, pencatatan data historical transaksi seorang anggota, kolom mediasi untuk mempermudah transaksi, mengecek status barang atau uang (tracking system), dan notifikasi melalui email maupun inbox member. Untuk memperkenalkan layanan yang disediakannya, PT "IPS" aktif bekerja sama dengan beberapa $e$ commerce, forum, dan group diskusi lainnya di internet. Selain itu, PT “IPS” belum memberikan biaya kepada member yang menggunakan layanannya, atau gratis. Pada saat ini sudah lebih dari 1500 transaki online per bulan memanfaatkan layanan PT "IPS”, hal ini menunjukan bahwa market dapat menerima layanan yang ditawarkan.

\section{Bagaimana Menghasilkan Profit dari Sebuah Ide?}

Fenomena belanja online yang terus meningkat, terutama yang disebabkan dari merebaknya pengguna situs social networking seperti facebook, twitter, atau myspace dan juga situs jual beli online yang sangat populer seperti kaskus, iklanbaris maupun tokobagus, merupakan suatu peluang bisnis yang dilirik oleh PT LPS. Ide mendirikan suatu wadah untuk menjembatani penjual dan pembeli ini di berawal dari kesulitan yang sering dihadapi para pembeli dan penjual online terutama jenis $\mathrm{C}$ to $\mathrm{C}$, atau konsumen yang menawarkan barang atau jasanya ke konsumen lain.

Kesulitan itu ada pada mekanisme settlement atau pembayaran yang digunakan pada belanja online. Pada umumnya, pada tipe transaksi barang (produk) C to C yang kemudian dilakukan dengan adanya pertemuan antara penjual dan pembeli, pembayaran akan dilakukan pada saat barang diterima atau COD (cash on delivery). Namun jika lokasi antara penjual dan pembeli berjauhan, barang harus dikirimkan melalui layanan jasa pengantaran, sehingga penjual akan meminta pembeli untuk melakukan pembayaran terlebih dahulu. Sesudah pembayaran diterima, barang akan dikirimkan. Dengan tipe settlement ini, resiko terdapat di pembeli, karena penjual tidak akan mengirimkan barangnnya sebelum uang diterima. Demikian juga sebaliknya, jika pembayaran dilakukan sesudah barang diterima, resiko akan berada pada pihak penjual.

PT “IPS”, kemudian membuat satu wadah yang dapat memberikan layanan jaminan atau garansi sehingga resiko di pihak pembeli maupun penjual dapat dikurangi, yaitu dengan cara: (1) negosiasi harga dilakukan di luar proses sistem PT "IPS". Pembeli atau penjual melakukan registrasi di website PT "IPS” (Gambar 4); (2) pembeli memberikan informasi pembelian yang dilakukannya melalui website PT “IPS”; (3) pembeli melakukan konfirmasi pembayaran ke PT "IPS"; (4) penjual melalukan konfirmasi pengiriman barang; (5) pembeli melakukan konfirmasi penerimaan barang; (6) penjual merima pembayaran dari PT “IPS”

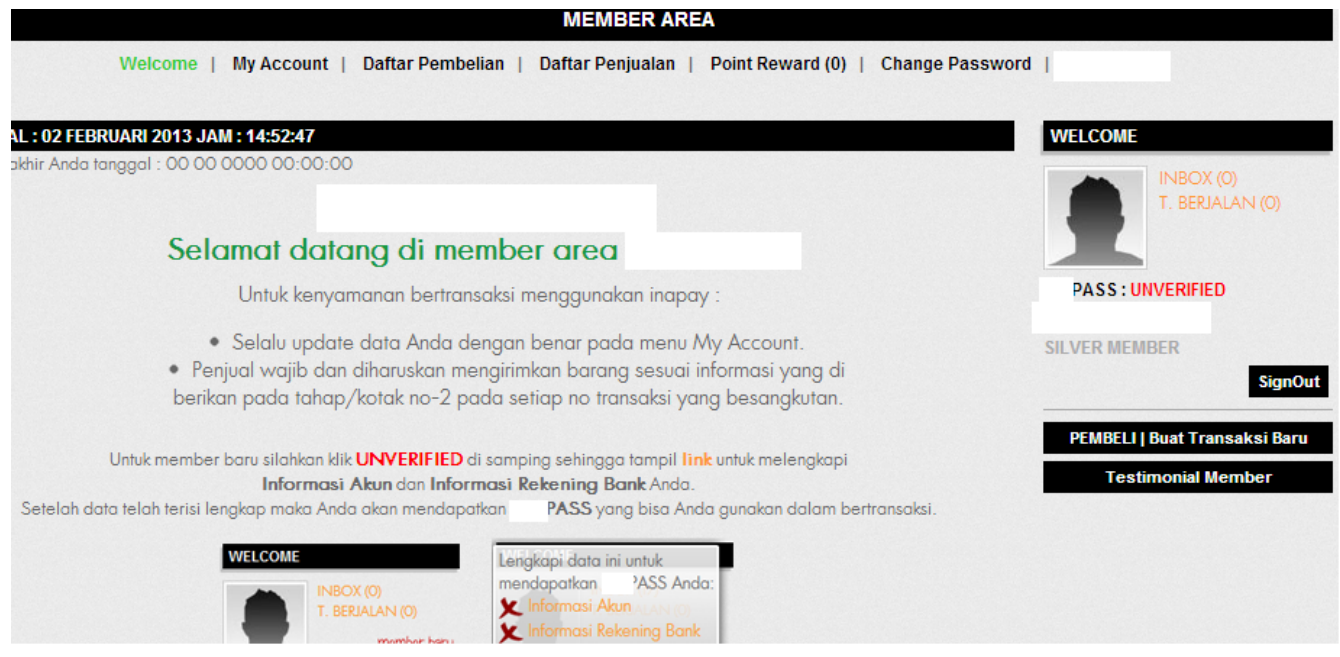

Gambar 4 Member area (Sumber : Website PT “IPS”) 
Sampai saat ini, memasuki tahun keduanya, PT "IPS” masih belum mengenakan biaya kepada membernya (Gambar 5). Lalu bagaimana cara PT "IPS” bisa menghasilkan profit dari usahanya ini? sementara tipe dari konsumen jual beli online $\mathrm{C}$ to $\mathrm{C}$ adalah pengguna yang selama ini tidak pernah mengeluarkan biaya didalam menggunakan layanan yang ditawarkan oleh dunia internet (e.g memposting iklan, games, layanan email, etc), dan juga merupakan pelanggan yang price sensitive.

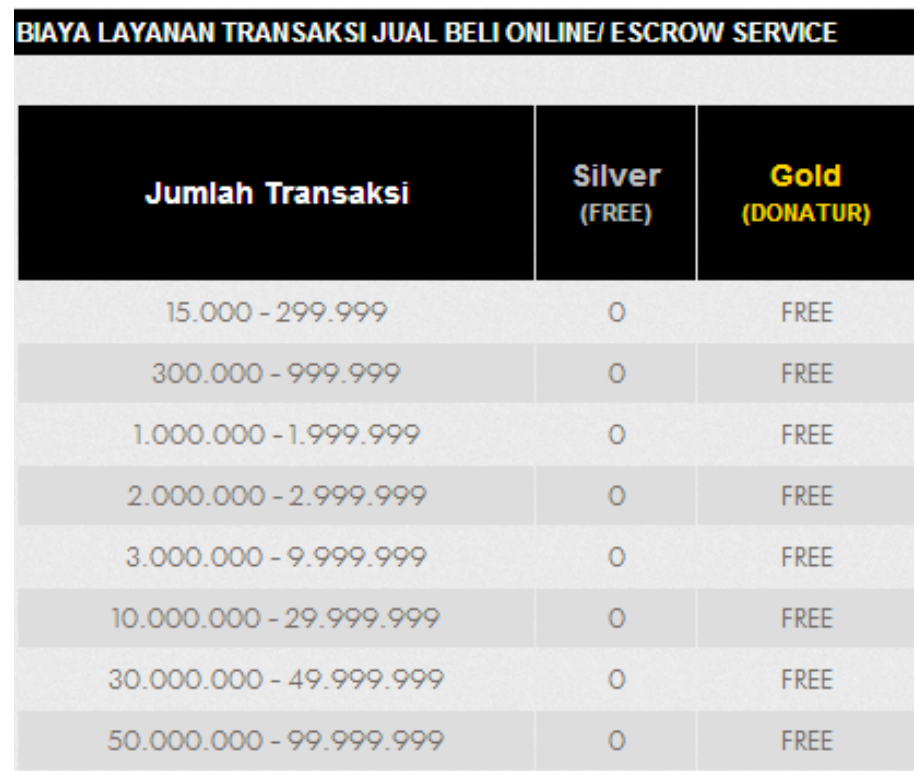

Gambar 5 Biaya layanan transaksi jual beli online (Sumber: website PT “IPS”).

Davis, Fred (1985) dan Jessup Umesh, Len dan Huynh, Minh Q (2007) mengemukakan bahwa faktor "attitude toward using" atau "intention to use the product" pada Technology Acceptance model (TAM), merupakan salah satu kunci perusahaan untuk mendapatkan keuntungan, karena akan menjadi pertimbangan customer apakah akan masih membeli produk atau jasa perusahaan itu. Pendekatan ini dikenal juga dengan metode populer dan sudah biasa digunakan oleh banyak perusahaan ntuk menentukan harga dari sebuah produk atau jasa yaitu customer value.

Perilaku konsumer atau user yang akan menentukan apakah PT "IPS” bisa mengenakan biaya kepada membernya tersebut. PT "IPS" perlu untuk menganalisa customer behaviour ini, bagaimana frekuensi penggunaannya? apakah penggunaan secara regular atau hanya one-off user -saja, dan mengencourage dari one-off user menjadi pengguna reguler. Dan hal itu sudah dilakukan oleh PT "IPS", dengan cara menerapkan sistem point reward untuk setiap membernya. Dikemudian hari, point tersebut bisa ditukarkan dengan gift atau merchandise yang dikeluarkan oleh PT "IPS".

Tetapi PT “IPS” masih perlu melakukan usaha lain untuk meningkatkan "intention” ini, misalnya seperti yang dilakukan oleh paypal.com (Gambar 6). Paypal menjual kemudahan dan keamanan kepada penggunanya sehingga pengguna dapat menggunakan pembayaran dengan menggunakan kartu kredit dengan aman dan mudah. 


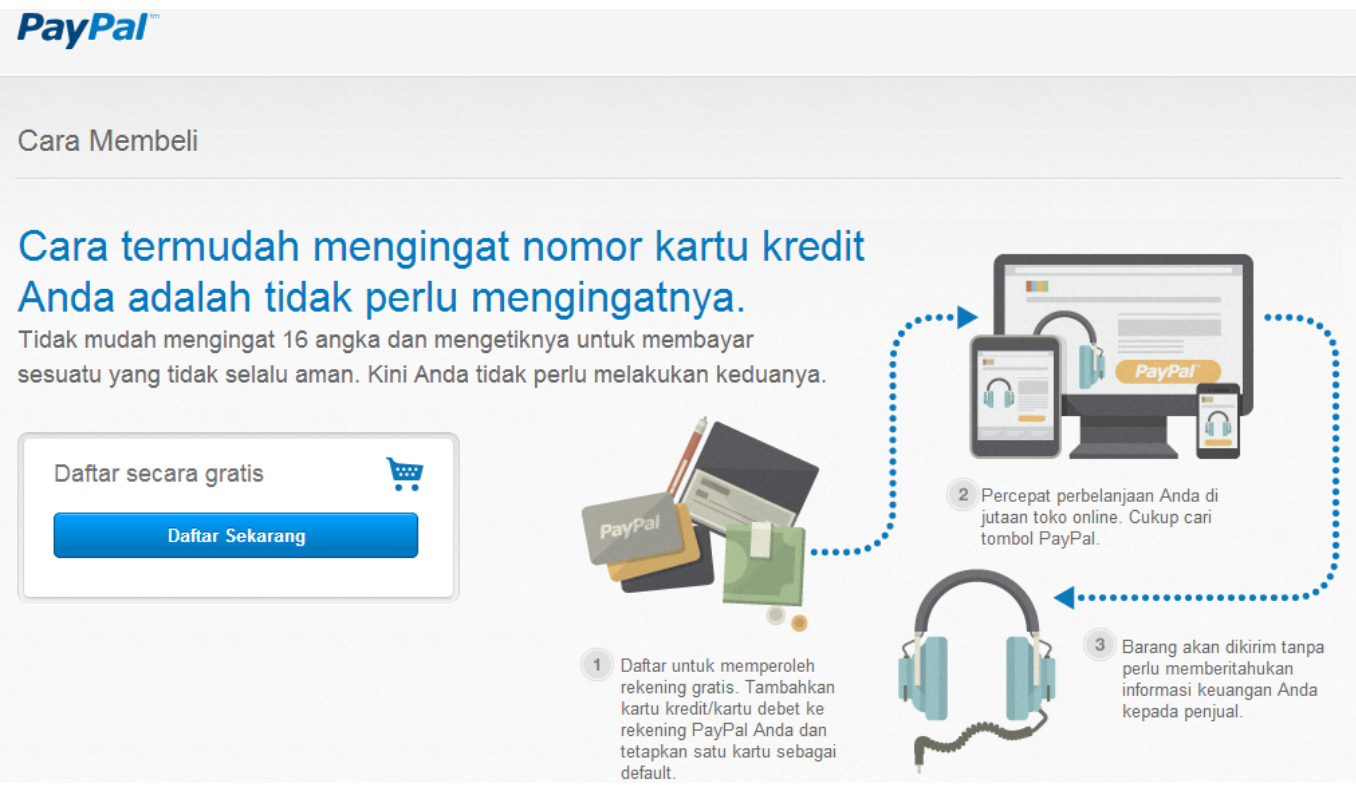

\begin{tabular}{l|l|l|l} 
PayPal & Beli & Jual & Kelola
\end{tabular}

\section{Keamanan}

\section{Perlindungan untuk pembeli dan penjual.}

Bagaimanapun cara Anda menggunakan PayPal, keamanan Anda adalah prioritas utama kami. Kami selalu merahasiakan informasi keuangan Anda, sehingga Anda tidak perlu memberitahukannya setiap kali melakukan pembelian.

Anda juga akan memperoleh perlindungan ekstra dengan teknologi pencegahan penipuan terbaru kami dengan pemantauan rekening setiap saat oleh tim spesialis keamanan kami. Selain itu, Anda juga akan mendapatkan tips dan alat untuk membantu memerangi pencurian identitas dan phishing serta proses yang mudah dan sederhana untuk melaporkan masalah.

Gambar 6 Paypal campaign mengenai keamanan dan kemudahan bertransaksi (sumber : website Paypal)

Selain itu, Paypal juga tidak membebankan biaya kepada semua membernya, paypal membedakan tipe member seperti pada Gambar 7. Paypal hanya membebankan biaya kepada akun bisnis, karena member mendapatkan layanan yang lebih dari paypal. PT "IPS" dapat mengadopsi metode yang sama dengan cara memberikan layanan yang lebih kepada pelaku bisnis sehingga pengguna mau terus untuk menggunakan layanan PT “IPS” dengan biaya tertentu. 


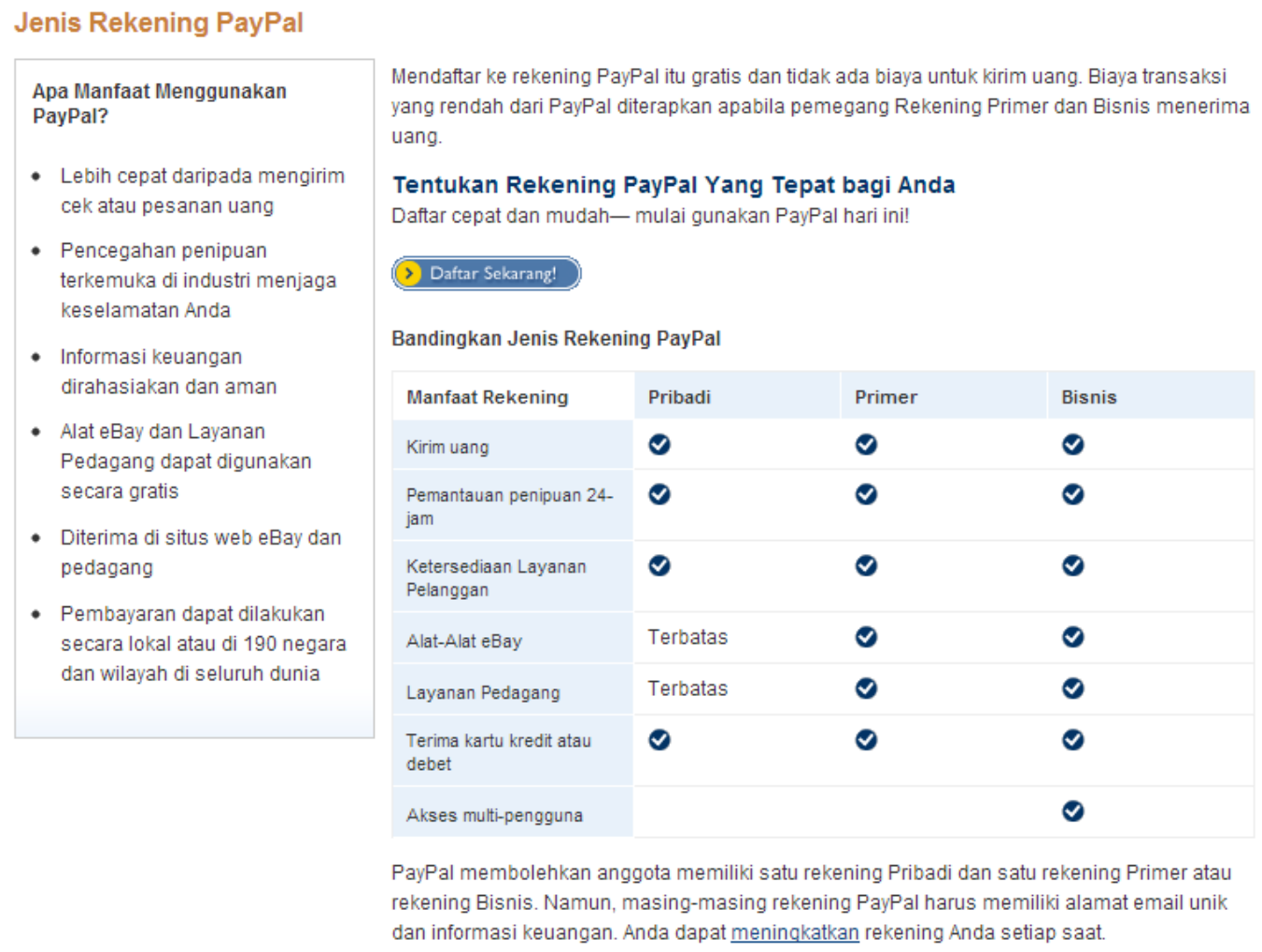

Gambar 7 Biaya penggunaan Paypal

Namun demikian, PT “IPS” juga masih tetap bisa mengenakan biaya kepada semua member. PT “IPS” bisa mengadopsi metode biaya yang dilakukan oleh pelaku bisnis di industri media, telekomunikasi, games maupun retail banking. Strategi penentuan harga yang dilakukan adalah dengan memberikan biaya serendah - rendahnya untuk suatu layanan atau produk sehingga biaya tersebut menjadi suatu biaya yang "diabaikan” atau tidak diperhitungkan oleh pelangganya, walaupun termasuk ke dalam kategori customer price sensitive. Contohnya adalah biaya yang di bebankan untuk billing statement seorang nasabah kartu kredit atau pelanggan telepon selular pasca bayar. Perusahaan hanya mebebankan sekitar 1000 atau 2000 rupiah per konsumen. Dengan harga serendah ini, banyak pelanggan yg akan mengabaikan sehingga pelanggan akan terus membayarnya. Bagi perusahaan, jika pelanggannya berjumlah 2 sampai 3 juta artinya merupakan penambahan pendapatan sebesar 2 sampai 6 miliar rupiah sebulan.

Demikian juga dengan Appstore (Gambar 8) yang menjual aplikasi permainan, film, musik atau buku dengan harga yang sangat murah, untuk pengguna produk Apple seperti iphone, ipad maupun ipod. Karena sangat murah, harga tersebut cenderung untuk diabaikan oleh pelanggan, dan pelanggan tidak berkeberatan untuk membayar. 


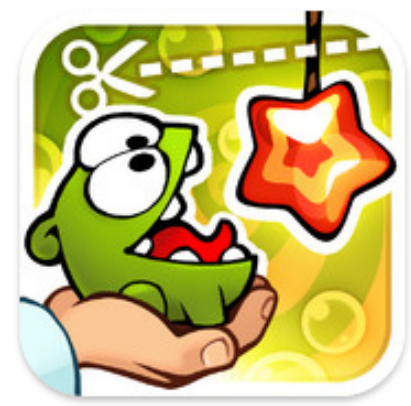

Rp 9.500 Buy App

\section{Cut the I}

\section{Descriptiol}

Experiment to fe more to come!

ZeptoLab UK Li

Category: Games

Updated: 29 November 2012

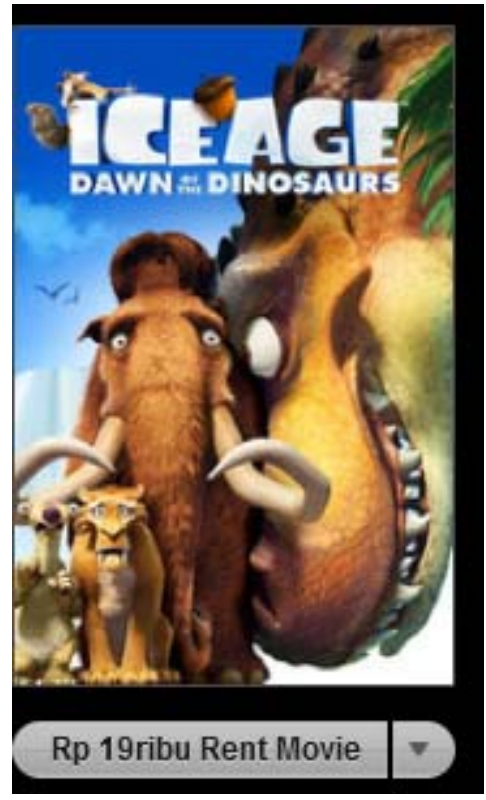

Music > Pop > Justin Bieber

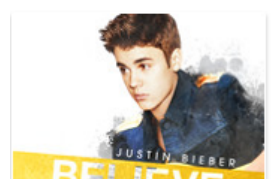

Believe Acoustic

\begin{tabular}{|c|c|c|c|c|}
\hline$\Delta$ & Name & Time & Popularity & Price \\
\hline 1 & Boyfriend (Acoustic Version) & 3:07 & 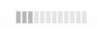 & Rp 7ribu BUY = \\
\hline 2 & As Long As You Love Me (Acoustic Version) & 3:41 & 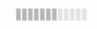 & Rp 7ribu BUY = \\
\hline
\end{tabular}

Gambar 8 Produk Appstore

Di samping itu PT “IPS” juga perlu untuk mencari peluang pendanaan lain yang bisa didapatkan dari jaringan bisnisnya itu, misalnya bekerja sama dengan perusahaan kurir atau delivery service, sehingga member PT "IPS" bisa mendapatkan harga yang lebih murah jika menggunakan perusahaan kurir yang bekerja sama dengan PT "IPS", dan PT "IPS" mendapatkan biaya dari kurir tersebut untuk setiap transaksi yang dilakukan oleh member PT "IPS". Selain itu sumber pendanaan bisa juga didapat dari penempatan iklan seperti yang banyak dilakukan perusahaan .com lainnya, atau membuka peluang bisnis pendukung seperti menyediakan layanan situs layanan jual beli online.

\section{PENUTUP}

Ide dan modal merupakan awal dari sebuah bisnis dapat terwujud, namun setelah dijalankan, IT entrepreneur akan menghadapi tantangan lainnya yaitu bagaimana menghasilkan keuntungan dari usahanya tersebut. Dengan menganalisa customer behaviour dan mengadopsi bagaimana pelaku bisnis lain mendapatkan profit, yaitu seperti terus meningkatkan intention pelanggannya untuk menggunakan produk dan jasanya atau meningkatkan value terhadap layanan produk dan jasanya, membebankan biaya kepada pelanggan tertentu yang mendapatkan pelayanan lebih, membebankan biaya serendahrendahnya kepada pengguna lainnya dan bekerja sama dengan perusahaan di bidang yang berhubungan dengan core bisnisnya, maka perusahaan diharapkan sudah dapat mendapatkan keuntungan dari usaha yang sudah dijalankannya tersebut. Penelitian perlu dilanjutkan setelah PT "IPS" mulai menerapkan strategi bisnis untuk mendapatkan profit, sehingga kita dapat melihat apakah inisiatif-inisiatif di atas dapat dijalankan dan merupakan solusi yang tepat untuk PT “IPS”. 


\section{DAFTAR PUSTAKA}

Apple. 92013). Apple Store. Diakses dari http://store.apple.com/us

Davis, F. (1985). A Technology Acceptance Model for Emirically Testing New End User Information System; Theory and Result.

Disertasi doktoral tidak diterbitkan. MIT Sloan School of Management, Cambridge, MA

Davis, F. (1989). Perceived usefullness, perceived ease of use, and user acceptance of information technology. MIS quarterly, 13 (3), 319 - 40

Gansa, Joshua S. dan Stern, Scott.(2002). The Product Market And The Market For "Ideas": Commercialization Strategies For Technology Entrepreneurs.. Evanston: Elsevier Science.

Paypal. (2013). Payment Methods. Diakses dari https://www.paypal.com/id/webapps/mpp/paymentmethods.

Umesh; Jessup, Len; Huynh, Minh Q (2007). Current issues faced by technology entrepreneurs: technology acceptance and market success model (TAMSA). Communication ACM, 5 (10), 60 $-66$. 